\title{
Targeting Protein for Xklp2
}

National Cancer Institute

\section{Source}

National Cancer Institute. Targeting Protein for Xk1p2. NCI Thesaurus. Code C116084.

Targeting protein for Xklp2 (747 aa, $\sim 86 \mathrm{kDa})$ is encoded by the human TPX2 gene. This protein plays a role in the formation of mitotic spindles. 